\title{
GEOLOGY
}

UDC 553.5:552.086:903.2

\author{
I. S. Nikitenko ${ }^{1}$, Cand. Sc. (Geol.), Assoc. Prof., \\ orcid.org/0000-0003-4207-2427, \\ O.V.Starik ${ }^{2}$, Cand. Sc. (History), \\ M. L. Kutsevol ${ }^{1}$, Cand. Sc. (Geol.), Assoc. Prof., \\ orcid.org/0000-0001-8718-2748, \\ S. V. Shevchenko ${ }^{1}$, Cand. Sc. (Geol.), Assoc. Prof., \\ orcid.org/0000-0003-3994-1927
}

DOI: $10.29202 /$ nvngu/2018-4/1

1 - National Mining University, Dnipro, Ukraine, e-mail: ihornikitenko@gmail.com

2 - Dnipropetrovsk National Historical Museum named after

D. I. Yavornytskyi, Dnipro, Ukraine, e-mail: segun.1@i.ua

\section{PETROGRAPHIC RESEARCH ON STONE TOOLS FROM THE MEGALITHIC CULT SITE OF TOKIVSKE-1}

Purpose. Determination of the stone raw materials resource base used by the populations of various historical epochs, who left their monuments in the territory of the stationary megalithic cult site in the village of Tokivske, Apostolove Raion, Dnipropetrovsk Oblast, Ukraine.

Methodology. The research was performed using the method of comparative petrographic analysis of stone artefacts and rocks from natural exposures in thin sections.

Findings. Twelve artefacts were analyzed: eight of the Bronze Age, one of the Early Iron Age (Scythian Culture) and one of the $17^{\text {th }}-18^{\text {th }}$ centuries, as well as two undated artefacts. As a result of petrographic analysis, they were divided into groups according to the stone materials from which they were produced: granites, metabasites, quartzites and quartz, schists, metasandstones and sandstones. Among the Bronze Age artefacts seven have local provenance from the village of Tokivske and the neighboring village of Sholokhove where a stone-processing workshop might have existed. The one imported tool is an amphibolite grinder, most likely brought from the middle section of the river Bazavluk. Concerning stone items of other epochs, a metasandstone plummet, dated to the $17^{\text {th }}-18^{\text {th }}$ centuries, apparently originated from Kryvyi Rih. The provenances of the remaining artefacts are somewhat ambiguous.

Originality. For the first time the archaeological finds from the megalithic stationary cult site Tokivske-1 were studied using mineralogical and petrographic analysis, and the probable sites of the stone mining for their production were determined.

Practical value. The obtained data indicates sites where ancient stone-processing workshops existed, being useful information for archaeological exploration. Also, the gathered information can be used for writing general works on archaeology and the history of mining.

Keywords: ancient mining, stone materials, stone tools, Bronze Age, Scythian culture, Cossacks, Tokivske

Introduction. Archaeological excavations in the village Tokivske, which is in Apostolove Raion, Dnipropetrovsk Oblast, Ukraine, have been carried out by an expedition of Dnipropetrovsk National Historical Museum named after D. I. Yavornytskyi since 2012 [1]. The object of research is the remains of the uncommon archaeological site that was given the name "stationary megalithic cult site Tokivske-1". It is located on the right bank of the river Kamianka. This area is known thanks to the landscape reserve "Kamianskyi riverside complex", among which there are a picturesque canyon and waterfalls. Geologically, this territory belongs to the area where the pink granites of the Tokivskyi complex crop out. This deposit is exploited in the village Tokivske, where facing-stone is produced for use in building.

(c) Nikitenko I. S., Starik O. V., Kutsevol M. L., Shevchenko S. V., 2018
The archaeological excavations in the territory of the Tokivske- 1 site showed the presence of two main cultural horizons. The lower one is dated to the Middle Bronze Age (Babine Cultural Circle), the upper one to the Early Iron Age (Scythian Culture). Sporadically, the fragments of ceramic and tools of the Early Bronze Age and the Cossacks period $\left(17^{\text {th }}-18^{\text {th }}\right.$ centuries $\left.A D\right)$ are being found. In 2016, the total area of the excavation was $359 \mathrm{~m}^{2}$. There were studied two artificial stone foundations, four cult pits, an altar (Fig. 1), a burial of the Early Iron Age, several fireplaces and ceramic and flint accumulations.

An important part of the collection of finds are stone items (Fig. 2). One of the crucial issues for the research of the archaeological complex in Tokivske is the provenance determination of the found stone artefacts' materials. This information can be obtained by petrographic 


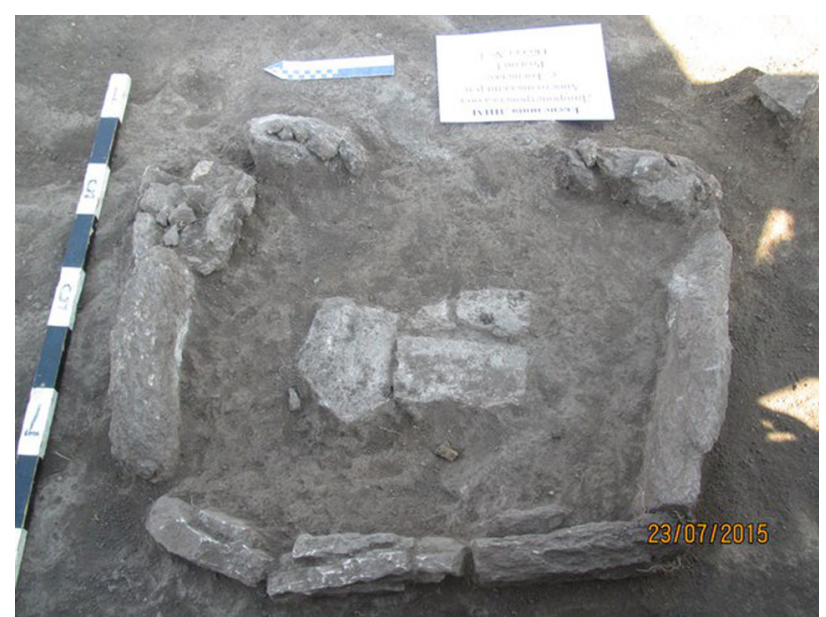

Fig. 1. Altar appearance during excavations. Pentagonal plate in the left-centre - specimen 7 (according to Table 1)

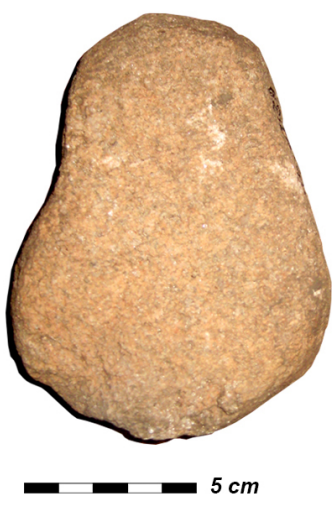

$a$
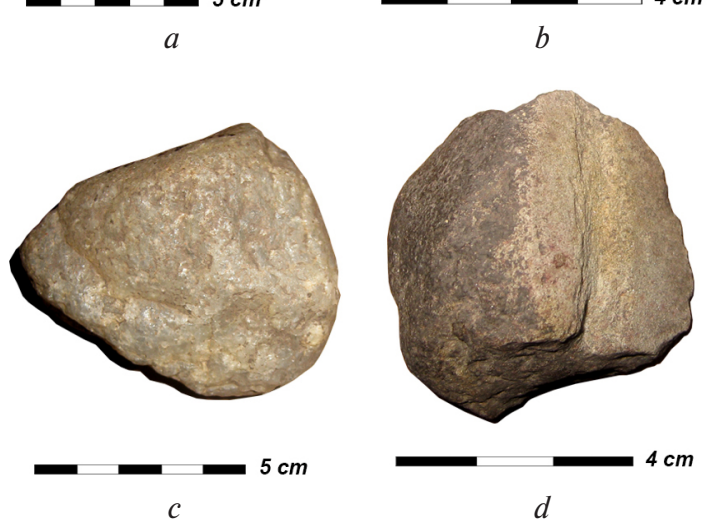

Fig. 2. Stone tools from the materials of excavation in the village Tokivske (numbers in brackets correspond to Table 1):

$a$ - grinder (1); $b$ - whetstone fragment (4); $c$ - grinder fragment (3); $d$-plummet (11)

analysis. Mineralogical and petrographic methods are among the most important in the study of stone artefacts. They make it possible to determine the material of a stone tool or monument as well as its provenance. Petroarchaeological methods permit the determination of ancient trade routes as well as the locations of mining processing. The current article is devoted to the results of mineralogical and petrographic research of stone artefacts that were found during the first five years of excavations (2012-2016).
Analysis of the recent research and publications. Nowadays, petrographic methods are widely used in world archaeological science in research of stone artefacts of different epochs such as grindstones [2], Neolithic polished stone tools made from greenstones [3], various stone products of the antiquity [4], etc. Petroarchaeological studies in the Middle Dnipro area were started as early as the middle of the last century by the founder of this area of research in Ukraine, Viktor Petrun. Stone tools of the Bronze Age were studied in 1980s by Iryna Sharafutdinova, and the petrographic research of Polovtsian stone stelae was carried out by Liubov Geraskova in 1991. Today, petroarchaeology in the region continues to evolve. Particularly, stone tools of the Bronze Age from the Middle Dnipro area were recently analyzed by the present authors and Serhii Lysenko [56]. Mining sites of the Bronze Age have not yet been found in the Middle Dnipro area. For now, the nearest big extraction places are found in Donbas [7].

Topicality. Today, Tokivske- 1 is one of the main archaeological objects of the Middle Dnipro area that are being studied. Its finds have never before been analyzed by petrographic methods. Hence, the research of stone artefacts from the excavations in Tokivske can supplement existing information about the history of rocks usage in this region. Especially important is the study of the items which belong to the aforementioned Bronze Age stationary megalithic cult site. Since this complex could serve as a center of a particular tribal association, the origin of stones could also outline the territory that belonged to it.

Objectives of the article. The purpose of the study was to determine stone raw materials resource base used by the populations of various historical epochs, who left their monuments in the territory of the stationary megalithic cult site Tokivske- 1 . In order to achieve the goal, it was necessary to conduct a mineralogical and petrographic study of stone products as well as to establish the provenance of the rocks from which they were made.

Materials and methods. To carry out the petrographic research, 12 stone items from the excavation materials were studied. Specimens for thin sections were taken only from damaged parts of artefacts in order to minimize harm. Thin sections were analyzed using a polarizing microscope, model POLAM R-314.

In order to determine the origin of raw materials of stone products, the results of mineralogical and petrographic analysis were compared with the literary data, as well as a collection of rock specimens from the Middle Dnipro area, from which thin sections had also been produced. In addition, some of the authors led several geological field practices for students in the area of the village Tokivske. As a result, a collection of rock specimens from this territory was created and a petrographic study of rocks similar to the raw materials of the studied artefacts was carried out.

Results. The raw material of every studied specimen was determined (Table 1). They were divided into groups according to the rocks from which they were made: metabasites, quartzites and quartz, schists, metasandstones, sandstones. 
List of studied artefacts

\begin{tabular}{|c|c|c|c|c|c|c|}
\hline No. & Name & $\begin{array}{l}\text { Inventory } \\
\text { number }\end{array}$ & $\begin{array}{c}\text { Finding } \\
\text { year }\end{array}$ & $\begin{array}{l}\text { Measurements, } \\
\mathrm{cm}\end{array}$ & Dating & Material \\
\hline 1 & Grinder & Temp. -14977 & 2012 & $11.5 \times 8.5 \times 2.5$ & Middle Bronze Age & Granite \\
\hline 2 & Grinder fragment & $\mathrm{NV}-37016$ & 2015 & $11.2 \times 4.0 \times 4.0$ & Middle Bronze Age & Amphibolite \\
\hline 3 & Grinder fragment & $\mathrm{NV}-37126$ & 2012 & $5.8 \times 5.5 \times 3.9$ & Bronze Age & Quartzite \\
\hline 4 & Whetstone fragment & NV - 37019 & 2015 & $5.8 \times 2.1 \times 1.4$ & Middle Bronze Age & Amphibolite \\
\hline 5 & Burnisher fragment & $\mathrm{NV}-37018$ & 2015 & $5.1 \times 1.3 \times 0.7$ & Middle Bronze Age & $\begin{array}{l}\text { Quartz-zoisite- } \\
\text { actinolite schist }\end{array}$ \\
\hline 6 & Fragment of a suboval grinder & NV -37017 & 2015 & $9.0 \times 7.9 \times 3.3$ & Middle Bronze Age & Metadolerite \\
\hline 7 & $\begin{array}{l}\text { Fragment of a plate from the } \\
\text { central part of altar }\end{array}$ & none & 2015 & $18.5 \times 13.0 \times 3.0$ & $\begin{array}{l}\text { Middle Bronze Age, } \\
\text { Babine Cultural Circle }\end{array}$ & Granite \\
\hline 8 & $\begin{array}{l}\text { Stone from the cult pit } \\
\text { bottom }\end{array}$ & $\mathrm{NV}-37314 / 1$ & 2015 & $20 \times 18 \times 8$ & Middle Bronze Age & Granite \\
\hline 9 & Stone tool fragment & none & 2016 & $6.5 \times 5.0 \times 1.5$ & unknown & Pyroxene quartzite \\
\hline 10 & Stele fragment (base) & none & 2016 & $8 \times 5 \times 2$ & unknown & Sandstone \\
\hline 11 & Plummet & $\mathrm{NV}-38418$ & 2016 & $3.8 \times 3.6 \times 2.2$ & $17^{\text {th }}-18^{\text {th }}$ century & Metasandstone \\
\hline 12 & Rock crystal (polished) & $N V-37020$ & 2015 & $3.7 \times 1.6 \times 1.5$ & $\begin{array}{l}\text { Early Iron Age } \\
\text { (Scythians?) }\end{array}$ & Quartz \\
\hline
\end{tabular}

Granites. These rocks are represented by three samples of the studied collection $(1,7-8)$. All of them can be identified as muscovite two-feldspar granites. The rocks of samples 7 and 8 are very similar. Sample 1 differs from the others in the ratio of plagioclase and microcline. Plagioclase prevails over microcline in this sample whereas alcali feldspar composes more than half of the rock volume in samples 7 and 8 .

Mineral content in the granite of sample 1 (vol. \%): plagioclase -40 , quartz -40 , microcline -15 , muscovite -4 , biotite $-<1$, sericite $-<1$ (replaces plagioclase), chlorite - single grains (partly replaces some biotite grains). The majority of feldspar and quartz grains have irregular shape which determines the allotriomorphic texture of the rock. Muscovite forms aggregates of flaky crystals varying in size. This is a characteristic of a secondary mineral and therefore we can conclude that the muscovite was formed metasomatically as a result of feldspar alteration.

The main minerals of samples 7 and 8 (vol. \%) are: microcline $-50-55$, quartz $-25-30$, plagioclase $-10-$ 15; the minor minerals are (in vol. \%): muscovite -5 , sericite and chlorite $-<1$ (Fig. 3). There is a distinction between the two samples: sample 8 contains single grains of biotite and epidote. In addition, the rock of this sample exhibits signs of cataclase. Microcline crystals in both samples have different degree of idiomorphism depending on their size. Namely, larger crystals have a regular, tabular shape while smaller grains have an irregular shape. Plagioclase is medium-grained in both samples; it has tabular and irregular shape and contains antiperthite inclusions, partially saussuritized and sericitized. Chlorite is poorly developed in biotite. In view of the fact that idiomorphic grains prevail in both rocks, their texture can be identified as hypidiomorphic-granular.
Granites provenance. Two-feldspar granites as part of the Tokivskyi, Demurynskyi and Mokromoskovskyi complexes are common in the Serednioprydniprovskyi (Middle Dnipro) megablock of the Ukrainian Shield [8, 9]. They also occur as microclinized areas in plagiogranites of the region [10].

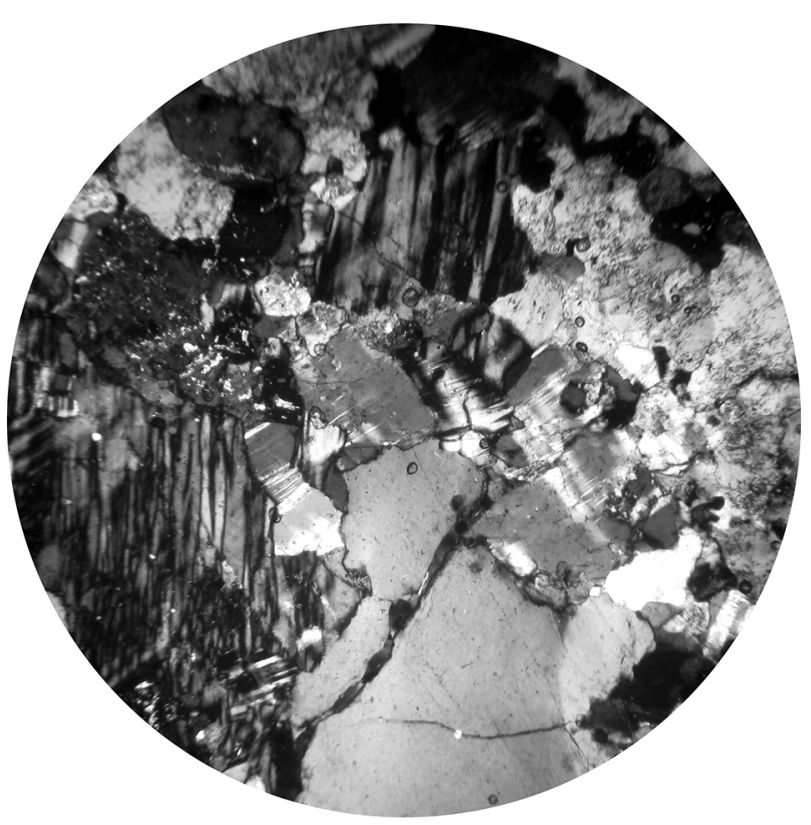

Fig. 3. Muscovite granite (8). Big crystals with crosshatched pattern - microcline; homogenous grains in the bottom and in the centre - quartz; light gray crystals with inclusions on the right - plagioclase; small light scales - muscovite. Transmitted light, crossed nicols, field of view $-2.7 \mathrm{~mm}$ 
The excavation zone is located within the area where Tokivskyi complex granites spread. The characteristics of samples 7 and 8 are very similar to those of Tokivskyi granites described in the literature. Local granite was sampled near the artefacts' place of discovery for comparison purposes. The petrographic analysis revealed similarity between this rock and the studied artefacts' raw material, with larger size of microcline grains being the only difference (Fig. 4).

Sample 1 is characterized by prevalence of plagioclase over microcline; its texture is similar to that of vein granites. Such varieties occur among the Tokivskyi massif granites and they also can be found among layered granitoids of the Dnipropetrovskyi complex (Scherbakov I.B., 2005). In addition, aplitoid granites cut through amphibolites of the Chortomlytska greenstone area which outcrop not far from Tokivske village, namely at Sholokhove village of Nikopol Raion, Dnipropetrovsk Oblast (Baranov P. N., 2009). Accordingly, the rock of artefact 1 could be either obtained near the archaeological site or brought there from another area. However, it is unlikely that material provenance was farther than the territory of the Serednioprydniprovskyi megablock of the Ukrainian Shield.

Metabasites. Three samples of the collection were attributed to metabasites: two samples of amphibolite (2, 4 ) and one sample of metadolerite (6).

Both amphibolite samples can be classified as leucocratic because their hornblende content is about half of the rocks' volume. In view of the fact that the rocks contain quartz they were identified as quartz amphibolites.

Mineral composition of sample 2 (vol. \%): hornblende -55 , plagioclase -36 , quartz -8 , opaque min-

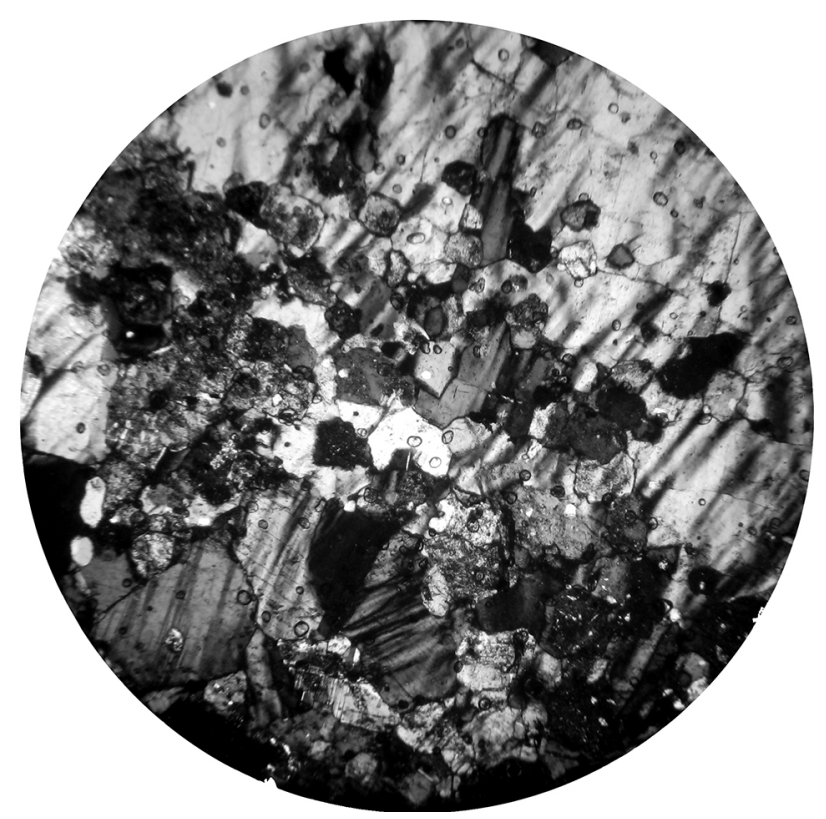

Fig. 4. Muscovite granite (natural exposure in Tokivske). Big crystals with cross-hatched pattern - microcline; small homogenous grains - quartz; small crystals with inclusions - plagioclase; small light scales muscovite and sericite. Transmitted light, crossed nicols, field of view $-2.7 \mathrm{~mm}$ eral -1 , biotite, goethite, clinozoisite, sericite, chlorite, apatite - less than one percent. Hornblende forms prismatic and elongated crystals (Fig. 5) and its color changes in the thin sections from blue-green to pale-green due to pleochroism; therefore the mineral appears similar to actinolite. Plagioclase grains display lamellar twinning. Biotite is a secondary mineral in the rock; it partly replaces hornblende. Goethite occurs in some biotite grains as a result of oxidation and also forms dispersed admixture in the rock. Clinozoisite, sericite and chlorite were formed in consequence of plagioclase alteration. Based on the shape and relationship of the grains, the rock's texture was identified as glomero-granoblastic.

The amphibolite of sample 4 has the following mineral composition (vol. \%): hornblende - 50, plagioclase -44 , quartz -4 , biotite -1 , opaque mineral -1 , apatite - less than one percent. Hornblende is shaped as small, mostly tabular crystals with characteristic diamond-like cleavage. Plagioclase crystals have tabular habit as well. Polysynthetic twins are observed in some of them. Several of the plagioclase grains are saussuritized. Quartz has irregular grain shape. Apatite occurs as inclusions in quartz. The texture of the rock is similar to one of the above-described amphibolite - fine-grained, glomero-granoblastic.

The metadolerite of sample 6 differs from the rest of the metabasites because its primary ophitic texture is preserved. Mineral composition of the rock (vol. \%): hornblende -64 , plagioclase -32 , biotite -2 , opaque mineral -2 , titanite - less than one percent. The hornblende grains have irregular and tabular shape, and include small plagioclase crystals. Plagioclase forms long rectangular grains with polysynthetic twins. It is a calcium-rich member of a series (labradorite-andesine) and is slightly saussuritized. The texture of the rock is blastophitic.

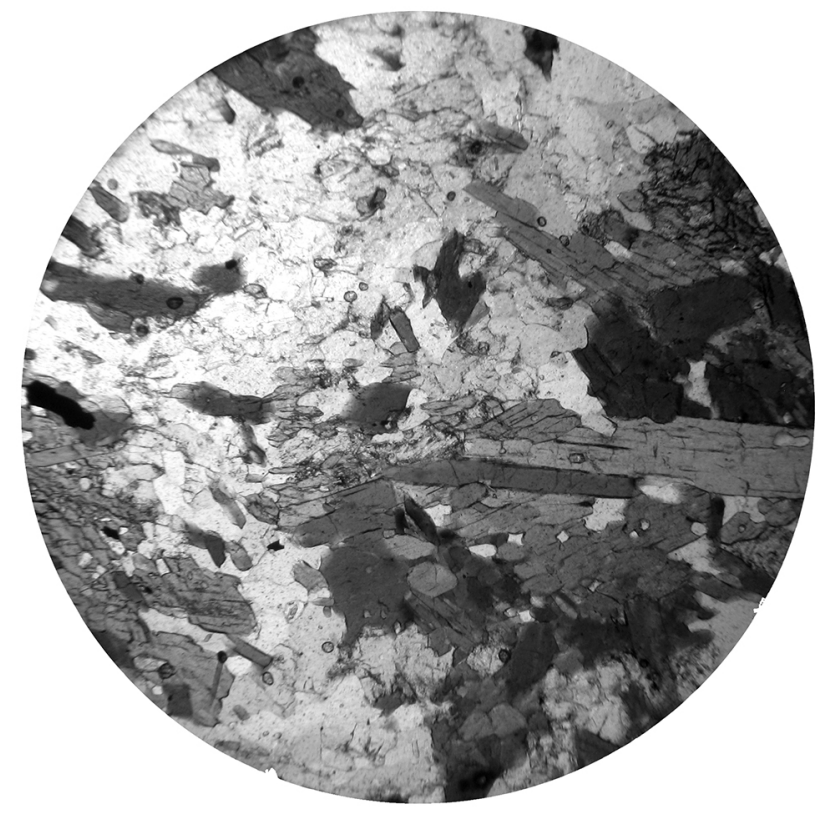

Fig. 5. Quartz amphibolite (2). Dark crystals with cleavage - hornblende; light grains - plagioclase and quartz. Transmitted light, parallel nicols, field of view $-2.7 \mathrm{~mm}$ 
Metabasites provenance. Metabasites are fairly common rocks in the Serednioprydniprovskyi megablock of the Ukrainian Shield. Usually they are part of greenstone complexes and occur as xenoliths among granitoids as well [11, 12]. The Tokivskyi granite complex is surrounded by three greenstone structures. The closest outcropped greenstones to the archaeological site belong to the Chortomlytska structure. In particular, there are large outcrops of amphibolites near Sholokhove village, on both banks of the river Solona. Another two greenstone structures, namely Kryvorizka and Sofiivs$\mathrm{ka}$, are located a little farther from the archaeological site in the north and northeast directions.

The amphibolite of sample 2 which has elongated hornblende crystals is not typical for the area of Sholokhove village because local amphibolite is composed of isometric hornblende and plagioclase grains. Microscopic study of a sample taken at Sholokhove village confirmed this conclusion. Considering such features as hornblende similarity to actinolite, hornblende crystals' shape and presence of minerals of the epidote group and the rock texture, sample 2 has the greatest similarity with amphibolites of the middle part of the river Bazavluk basin. These rocks belong to the Sofiivska structure and crop out near Malosofiivka village of Krynychanka Raion, Dnipropetrovsk Oblast (Usenko I. S., 1953).

Sample 4 is similar to Sholokhove amphibolites, it differs from them only in grain size. One possible explanation of this fact is that the rock was taken from a contact zone. Metadolerites or amphibolites with preserved ophitic texture, as seen in sample 6, are common among rocks of the Kryvorizka and Sofiivska greenstone structures. However, calcium-rich plagioclase is replaced by albite in metadolerites of the Kryvorizka structure outcropping along the river Saksahan, which makes those rocks dissimilar to the studied sample. Aside from the Sofiivska greenstone structure metadolerites occur in dikes of the Middle Dnipro area. Usenko I.S. noted natural outcrops of such rocks along the rivers Bazavluk, Solona, Kamianka, Chortomlyk and Mokra Sura. According to his data, primary pyroxenes in the rocks were replaced by hornblende while labradorite remained unchanged. Biotite and titanite are present as minor minerals in those rocks as well as in the metadolerite of sample 6. Rocks with higher content of albite fraction in plagioclase (labradorite-andesine) as seen in the studied sample 6 are less common. The dike located near the river Bazavluk upstream of Sholokhove village was mentioned by I. S. Usenko as the most important outcrop of such diabase (Usenko I. S., 1952). Therefore, the rock of the artefact, most likely, has local provenance.

Quartzites and quartz. Two samples of the collection were identified as quartzites. One of them is almost monomineralic quartz rock (3) and the other (9) contains a pyroxene impurity. Sample 12 is a quartz crystal (rock-crystal).

The rock of sample 3 was difficult to attribute to either quartzite or vein quartz. The rock is composed entirely of quartz and has granoblastic texture. Sample 9 is identified as a metamorphic rock more reliably. Its mineral composition is (vol. \%): quartz - 90, orthopyrox- ene -8 , opaque mineral -1 , goethite -1 . Quartz forms isometric grains of various sizes. It has undulatory extinction. According to its optical features, the orthopyroxene can be identified as hypersthene. The mineral forms irregular and isometric grains and demonstrates weak pleochroism from pale pink to greenish gray color. Goethite has yellow color and is developed over cracks in the rock. The rock texture was identified as heterogranoblastic.

The rock-crystal sample was not studied by means of petrographic analysis due to its value. The rock presents as a trimmed quartz crystal of a characteristic shape.

Quartzites and quartz provenance. Veins of quartz that are similar to the rock of sample 3 are common among numerous complexes of the Ukrainian Shield. The nearest outcrops are known both in the rocks of the Tokivskyi granitic complex and in adjacent areas. The Tokivske outcrop of vein quartz is located to the south of Chervony Zaporozhets village, which is near the river Kamianka a little upstream from the archaeological site. A large outcrop of similar vein quartz, enclosed in plagiomigmatites of the Dnipropetrovskyi complex, is also situated not far from the artefacts' place of discovery, namely at the south-western outskirts of the village Sholokhove, on the right bank of the river Bazavluk. A subvertical quartz vein up to $25 \mathrm{~m}$ in thickness was developed as silica raw materials for the Zaporizhzhia Metallurgical Plant before World War II. All the abovementioned vein quartz has pink to gray and white color and almost monomineralic composition (Baranov P. N., 2009). Therefore sample 3 may well have local provenance.

Quartzite containing pyroxenes (9) is a quite rare rock. Its genesis is associated with the processes of metasomatism. Pyroxene quartzites are found as part of the upper formation of the Kryvorizka structure in the Serednioprydniprovskyi megablock, namely in the Zhovtorichenske and Proletarske deposits (Baranov P. N., 2010). Natural outcrops of such rocks are not known nowadays, but they could have existed in ancient times.

Rock crystal (e.g., sample 12) was a traditional stone for adornment in Scythian culture [13], commonly used throughout its range. Crystal quartz is typical for pegmatites of the Ukrainian Shield, including the Serednioprydniprovskyi megablock. It occurs together with vein quartz as well. In particular, quartz druses of the outcrop near Sholokhove village were studied in the Gemological Center of the National Mining University. However, considering the value of the stone it might have been brought from more remote areas.

Schists. Quartz-zoisite-actinolite schist (sample 5) was attributed to this group. Mineral contents in the rock (vol. \%): actinolite -55 , zoisite -34 , quartz -10 , opaque mineral -1 . Actinolite forms grains of irregular shape and acicular crystals, with the latter oriented subparallel. Zoisite and quartz have isometric grains and similar grain size. The texture of the rock is granonematoblastic, fine-grained, the structure is linear.

Schist provenance. The above described rocks have metasomatic genesis and can be found locally as part of gneiss-migmatite complexes. In the vicinity of the exca- 
vation zone such rocks occur northwest of Sholokhove village, near the outcrop of amphibolites. The host amphibolites are cut through by veins of aplitoid granite, aplite, pegmatite, quartz, and comprise layers of migmatites and other kinds of metasomatic rocks: albite-amphibole, zoisite and quartz-zoisite-amphibole. The studied sample belongs to the last one listed. The genesis of all the vein rocks is associated with the postmagmatic phase of the Tokivskyi massif formation (Baranov P. N., 2009).

Metasandstones. These rocks are represented by sample 11. The rock of the sample is sericite metasandstone. Mineral composition of the rock (vol. \%): quartz -84 , sericite -14 , biotite $-<1$, opaque mineral -1 . Quartz grains are tightly compacted, but primary texture of a fine-grained sandstone can still be detected. Sericite forms aggregates of flakes in place of primary pore-filling cement. The texture of the rock can be identified as blasto-psammitic (Fig. 6).

Metasandstone provenance. Metasandstones similar to the one described above are common among the Skeliuvatska suite of the Kryvorizka series sediments [14]. Nowadays, large outcrops of such rocks are located on the left bank of the river Inhulets, near Pivdenny Mining and Processing Plant in Kryvyi Rih city, which is at a distance of $60 \mathrm{~km}$ from the artefact's place of discovery. Therefore, the rock is likely to have Kryvyi Rih area provenance.

Sandstones. One sample of the collection (10) is a sandstone. The rock was identified as ferruginous arenite. The framework of the rock is composed of quartz (99\%), with minor microcline and plagioclase grains (up to $1 \%$ ). The clastic grains are angular to rounded, $0.1-0.3 \mathrm{~mm}$ in size, which corresponds to a fine-grained texture. The rock cement is composed of goethite. The cement is of contact type in some areas and basal type in the others. The rock structure is psammitic.

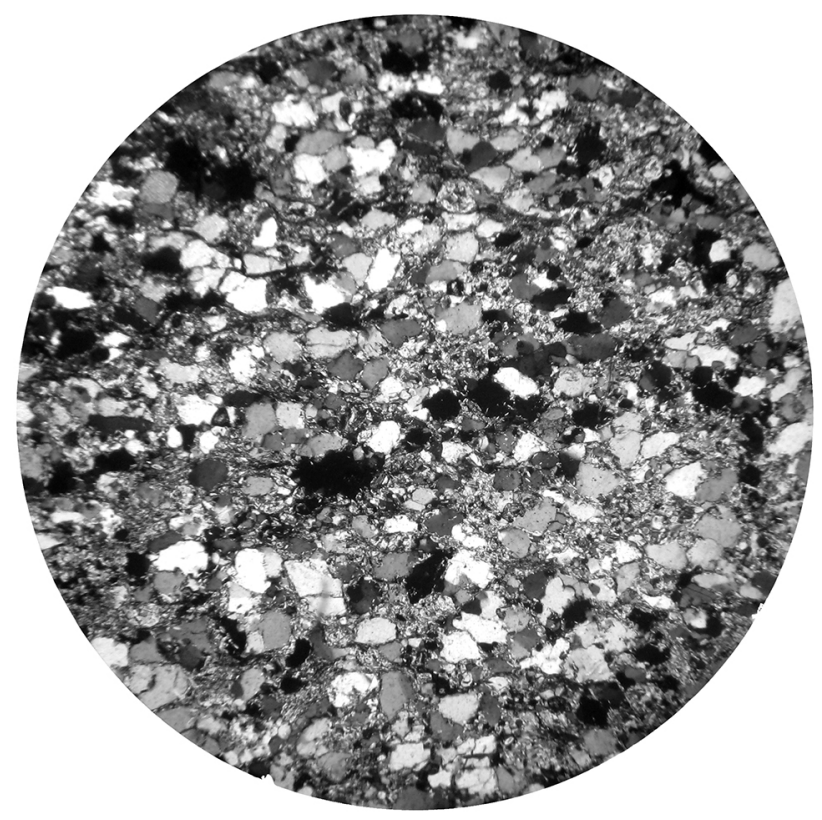

Fig. 6. Sericite metasandstone (11). Isometric grains quartz; microscales - sericite. Transmitted light, crossed nicols, field of view $-2.7 \mathrm{~mm}$
Sandstone provenance. Quartz sandstone with ferruginous cement is a widespread rock. It occurs as deposits and small outcrops among sands throughout the entire territory of Ukraine, in sediments of various age: from Permian (Donbas area) to Neogene (Middle Dnipro area). Sandstones, particularly ferruginous ones, are less common on the right bank of Dnipro River as compared to the left bank area. A single significant outcrop of such sandstones in the vicinity of the artefact's place of discovery is found in ravine Hlyniana located one kilometre south of Fedosiivka village of Nikopol Raion, Dnipropetrovsk Oblast. Lumps of coarse-grained ferruginous sandstone are exposed among sand in abandoned quarries in this area (Vidergauz L. M., 1964). It should be considered, however, that the sample is a fragment of a statue with an unknown date of production. Stone blocks suitable for statue crafting must have a certain size (more than one meter across), whereas lumps of ferruginous sandstone occurring in the Middle Dnipro area almost never reach this size. If the stele belonged to Polovtsian stone babas, the provenance of the raw material could be more remote. For instance, L. S. Geraskova identified the provenance of Polovtsian babas made of similar rocks as Permian sandstones from the Donbas area (Geraskova L.S., 1991). Therefore, if the studied stele is dated as medieval, such provenance is also possible.

Conclusions. Summarizing obtained data, the Bronze Age stone artefacts should be considered separately from the rest of the items.

The majority of the artefacts dated to the Bronze Age are of local provenance and their raw material, most likely, was extracted in the vicinity of the villages Tokivske and Sholokhove. Among imported items is an amphibolite grinder, which, more likely, was carried from the area around the village Malosofiivka in the middle stream of the river Bazavluk that is a distance of $80 \mathrm{~km}$ from the place of finding. The tool produced from pyroxene quartzite, for which dating and cultural belonging is unknown, most likely was delivered from the north of Kryvyi Rih Basin (more than $100 \mathrm{~km}$ distant). If this item also belongs to the artefacts of the Bronze Age, this fact widens the provenance geography of stone tools dated to this epoch. It is important to mention that there are only two artefacts that originate exactly from the area of the village Tokivske; these are the stone plate from the altar and a stone from the cult pit filling. Meanwhile, functional tools, even those produced from granite, were delivered from the area of Sholokhove. It should be noted that there are 8 known settlements of different times recorded in the vicinity of this village (general chronology: $2^{\text {nd }}$ millennia $\mathrm{BC}-4^{\text {th }}$ century AD), with 5 of them belonging to the Bronze Age [15]. The archaeological material from most of these settlements contained stone tools such as grinders, hammerstones, whetstones, etc., or fragments thereof. The synchronicity of these settlements with the stationary megalithic cult place Tokivske- 1 is obvious. Thus, we can suppose the connection between these two complexes as well as the existence of a stone-processing workshop in the vicinity of the village Sholokhove. 
The finding of tools produced from nonlocal stone indicates that the cult place was visited by representatives of other territories. As was ascertained, these stone materials originated from the north, particularly from the area upstream of the Bazavluk River. Probably, this territory (the whole Bazavluk basin) belonged to one tribal union and the cult complex in Tokivske served as one of its religious or political centers.

Concerning stone goods of other epochs, it can be stated that the plummet, which dates to the $17^{\text {th }}-18^{\text {th }}$ centuries, most probably was carried from the Kryvyi Rih area. The material of the stone baba may be local, but in case it belongs to Polovtsian culture, the statue may originate from the territory of Central Donbas. The Scythian item produced from the rock crystal may have either a local or remote origin.

\section{References.}

1. Starik, O. and Proshnychenko, M., 2013. Archaeological exploration in the village Tokivske, Apostolove Raion, Dnipropetrovsk Oblast. Archaeology \& Fortification of the Middle Dniester area. Collected materials of the $3^{\text {rd }}$ All-Ukrainian scientific and practical conference. Kamianets-Podilskyi, pp. 56-60 [online]. Available at: $<$ http://muzeum.in.ua/files/\%D0\%97\%D0\% B1\%D1 $\% 96 \%$ D1\%80\%D0\%BD\%D0\%B8\%D0\%BA_2013.pdf $>$ [Accessed 28 January 2017].

2. Burton, M. M., Muniz, A.A., Abbott, P.L., Kimbrough, D. L., Haproff, P.J., Gehrels, G. E. and Pecha, M., 2014. Sourcing sandstone cobble grinding tools in southern California using petrography, U-Pb geochronology, and $\mathrm{Hf}$ isotope geochemistry. Journal of Archaeological Science, 50, pp. 273-287.

3. Giustetto, R., Perrone, U. and Compagnoni, R., 2016. Neolithic polished greenstone industry from Castello di Annone (Italy): minero-petrographic study and archaeometric implications. European Journal of Mineralogy, 28, pp. 889-905.

4. Miletić, S., Kramar, S., Lux, J., Šmuc, A. and Zupančič, N., 2016. Provenance analysis of Roman stone artefacts from sedimentary rocks from the archaeological site near Mošnje, NW Slovenia. Geologija, 59/1, pp. 35-54.

5. Nikitenko, I. S. and Lysenko, S. D., 2014. Results of the mineralogical and petrographic analysis of stone goods from the burial ground Malopolovetskoye-3 and the settlement Malopolovetskoye-2A (Kiev Region). Stratum Plus, 2, pp. 333-345.

6. Nikitenko, I.S. and Kutsevol, M. L., 2016. On raw materials of Neolithic stone hoes from the Dnieper rapids area. Naukovyi Visnyk Natsionalnoho Hirnychoho Universytetu, 4, pp. 5-12.

7. Dorofeev, V.N., Brovender, Yu.M., Gajko, G.I., 2003. Ancient mines in Seversky Donets Basin. Gornyi Zhurnal, 11, pp. 72-73. Available at: http://www.rudmet. ru/journal/1086/article/17857/ [Accessed 28 April 2018]. 8. Ponomarenko, O., Kurylo, S. and Kovalenko, O., 2014. Main morphological types of zircon crystals from two-feldspar granitoids of Middle-Dnieper megablock of the Ukrainian Shield. Mineralogical Review, 1(64), pp. $80-89$.
9. Stepaniuk, L. M., Kurylo, S. I. and Kotvitska, I. M., 2016. Possible sources of original magmas of two-feldspar granites and conditions of magma generation (on the example of the Middle Dnieper megablock of USh). Mineralogical Journal, 3(38), pp. 81-91.

10. Sukach, V., Kurylo, S. and Grinchenko, O., 2016. Tonalite-throndemite-granodiorite (TTG) associations of the Middle Dnieper Archean craton. Visnyk Taras Shevchenko National University of Kyiv. Geology, 1(72), pp. 20-27.

11. Sukach, V. V., 2015. Petrogenesis of Auly series amphibolites in Bazavluchok river basin, Middle Dnipro megablock of the Ukrainian Shield. Mineralogical Journal, 1(37), pp. 69-85.

12. Kostenko, M. M., 2016. Geotectonic zoning of Ukrainian Shield as the basis of tectonic, stratigraphic and of other constructions. Zbirnyk naukovykh prats UkrDHRI, 3, pp. 144-163.

13. Klochko, L. S., 2016. Anklets in suits of Scythia population (in the Forest-Steppe Left Bank Dnipro region). Pratsi Tsentru pamiatkoznavstva, 29, pp. 94-101.

14. Paranko, I. S. and Matischuk, O. A., 2014. On the issue of stratification of Skelevatka suite of Kryvyi Rih series. Zbirnyk naukovykh prats UkrDHRI, 1, pp. 140-149. 15. Romashko, O. V., 2016. Archaeological essay. In: N. H. Pershina, ed., 2016. Monuments of History and Culture of Apostolovskyi Raion. Dnipro: Zhurfond, pp. 6-40.

\section{Петрографічне дослідження кам'яних виробів з мегалітичного культового місця Токівське-1}

\section{I. С. Нікітенко ${ }^{1}$, О. В. Старік², М. Л. Куцевол' ${ }^{1}$, С. В. Шевченко}

1 - Державний вищий навчальний заклад „Національний гірничий університет“, м. Дніпро, Україна, е-mail: ihornikitenko@gmail.com

2 - Дніпропетровський Національний історичний музей імені Д.І.Яворницького, м. Дніпро, Україна, e-mail: segun.1@i.ua

Мета. Визначення ресурсної бази кам'яної сировини, що використовувалася представниками різних епох, котрі залишили свої пам'ятки на території мегалітичного стаціонарного культового місця у с. Токівське Апостолівського району Дніпропетровської області.

Методика. Дослідження було виконано методами порівняльного мінералого-петрографічного аналізу сировини кам'яних артефактів і гірських порід із природних відслонень у шліфах.

Результати. Було вивчено 12 предметів, датованих епохою бронзи (8), скіфським часом (1), XVIIXVIII століттями (1), а також два артефакти без датування. У результаті мінералого-петрографічного аналізу досліджені зразки були поділені на групи відповідно до видів гірських порід, з яких вони були виготовлені: граніти, метабазити, кварцити й кварц, кристалічні сланці, метапісковики, пісковики. Серед кам'яних знахідок, що датуються епохою бронзи, сім мають місцеве походження з с. Токів- 
ське, а також сусіднього с. Шолохове, де могла існувати каменеобробна майстерня. Привізним знаряддям є амфіболітовий розтиральник, що, найвірогідніше, був доставлений з середньої течії р. Базавлук. Стосовно кам'яних виробів інших епох, то метапісковикове грузило, що датується XVIIXVIII ст., найімовірніше походить із Криворіжжя. Решта артефактів має кілька варіантів походження.

Наукова новизна. Уперше за допомогою мінералого-петрографічного аналізу були досліджені археологічні знахідки з каменя, що походять 3 мегалітичного стаціонарного культового місця Токівське-1, а також встановлені ймовірні місця видобутку кам'яної сировини для їх виготовлення.

Практична значимість. Отримані дані вказують на місця існування стародавніх каменеобробних майстерень, що може бути використано археологами для їх пошуків. Також, отримана інформація може застосовуватись для написання узагальнюючих робіт з археології та історії гірничої справи.

Ключові слова: стародавнє гірництво, кам'яна сировина, кам'яні вироби, доба бронзи, скіфська культура, козацтво, Токівське

\section{Петрографическое исследование каменных изделий из мегалитического культового места Токовское-1}

\section{И. С. Никитенко ${ }^{1}$, А. В. Старик², М. Л. Куцевол ${ }^{1}$, С. В. Шевченко ${ }^{1}$}

1 - Государственное высшее учебное заведение „Национальный горный университет“, г. Днепр, Украина, e-mail: ihornikitenko@gmail.com

2 - Днепропетровский Национальный исторический музей имени Д. И. Яворницкого, г. Днепр, Украина, e-mail: segun.1@i.ua

Цель. Определение ресурсной базы каменного сырья, которое использовалось представителями различных исторических эпох, оставившими свои памятники на территории мегалитического стационарного культового места в с. Токовское Апостоловского района Днепропетровской области.
Методика. Исследование было выполнено методами сравнительного минералого-петрографического анализа сырья каменных артефактов и горных пород из естественных обнажений.

Результаты. Было изучено 12 предметов, датированных эпохой бронзы (8), скифским временем (1), XVII-XVIII вв. (1), а также два артефакта без датировки. В результате минералого-петрографического анализа исследованные образцы были разделены на группы по видам горных пород, из которых они были изготовлены: граниты, метабазиты, кварциты и кварц, кристаллосланцы, метапесчаники, песчаники. Среди каменных находок, датированных эпохой бронзы, семь имеют местное происхождение из с. Токовское, а также соседнего с. Шолохово, где могла существовать камнеобрабатывающая мастерская. Привозным орудием является амфиболитовый терочник, который, наиболее вероятно, был доставлен из среднего течения р. Базавлук. Относительно каменных изделий других эпох, метапесчаниковое грузило, датируемое XVII-XVIII вв., вероятнее всего происходит из Криворожья. Остальные артефакты имеют несколько вариантов происхождения.

Научная новизна. Впервые при помощи минералого-петрографического анализа были исследованы археологические находки из камня, происходящие из мегалитического стационарного культового места Токовское-1, а также установлены вероятные места разработки каменного сырья для их изготовления.

Практическая значимость. Полученные данные указывают на места существования древних камнеобрабатывающих мастерских, что может быть использовано археологами для их поисков. Также, полученная информация может применяться для написания обобщающих работ по археологии и истории горного дела.

Ключевые слова: древнее горное дело, каменное сырье, каменные изделия, бронзовый век, скифская культура, казачество, Токовское

Рекомендовано до публікації докт. геол. наук М. В. Рузіною. Дата надходження рукопису 15.05.17. 